\title{
Active-layer thermal monitoring on the Fildes Peninsula, King George Island, maritime Antarctica
}

\author{
R. F. M. Michel ${ }^{1}$, C. E. G. R. Schaefer ${ }^{2}$, F. M. B. Simas $^{2}$, M. R. Francelino ${ }^{2}$, E. I. Fernandes-Filho ${ }^{2}$, G. B. Lyra ${ }^{3}$, and \\ J. G. Bockheim ${ }^{4}$ \\ ${ }^{1}$ Universidade Estadual de Santa Cruz, Ilhéus, Brazil \\ ${ }^{2}$ Universidade Federal de Viçosa, Viçosa, Brazil \\ ${ }^{3}$ Universidade Federal Rural do Rio de Janeiro, Seropedica, Brazil \\ ${ }^{4}$ University of Wisconsin, Madison, USA \\ Correspondence to: R. F. M. Michel (roberto@michel.com)
}

Received: 31 March 2014 - Published in Solid Earth Discuss.: 1 July 2014

Revised: 10 November 2014 - Accepted: 17 November 2014 - Published: 21 December 2014

\begin{abstract}
International attention to climate change phenomena has grown in the last decade; the active layer and permafrost are of great importance in understanding processes and future trends due to their role in energy flux regulation. The objective of this paper is to present active-layer temperature data for one Circumpolar Active Layer Monitoring South hemisphere (CALM-S) site located on the Fildes Peninsula, King George Island, maritime Antarctica over an 57-month period (2008-2012). The monitoring site was installed during the summer of 2008 and consists of thermistors (accuracy of $\pm 0.2^{\circ} \mathrm{C}$ ), arranged vertically with probes at different depths, recording data at hourly intervals in a highcapacity data logger. A series of statistical analyses was performed to describe the soil temperature time series, including a linear fit in order to identify global trends, and a series of autoregressive integrated moving average (ARIMA) models was tested in order to define the best fit for the data. The affects of weather on the thermal regime of the active layer have been identified, providing insights into the influence of climate change on permafrost. The active-layer thermal regime in the studied period was typical of periglacial environments, with extreme variation in surface during the summer resulting in frequent freeze and thaw cycles. The active-layer thickness (ALT) over the studied period shows a degree of variability related to different annual weather conditions, reaching a maximum of $117.5 \mathrm{~cm}$ in 2009 . The ARIMA model could describe the data adequately and is an important tool for more conclusive analysis and predictions when longer data sets are available. Despite the vari-
\end{abstract}

ability when comparing temperature readings and ACT over the studied period, no trend can be identified.

\section{Introduction}

International attention to climate change phenomena has grown in the last decade, and intense modeling of climate scenarios was carried out by scientific investigations researching the sources and trends of these changes (Mora et al., 2013; IPCC, 2012; Moss et al., 2010). The cryosphere and its energy flux became the focus of many investigations, being recognized as a key component of climate for the understanding of actual (climate variability) and future trends (Ledley, 1985; Flanner et. al., 2011; van den Broeke et. al., 2008). The active layer and permafrost, part of the terrestrial cryosphere, are of great importance due to their role in energy flux regulation and sensitivity to climate change (Kane et al., 2001; Smith and Brown, 2009). Compared to other regions of the globe, our understanding of Antarctic permafrost is poor, especially in relation to its thermal state and evolution, physical properties, links to pedogenesis, hydrology, geomorphic dynamics, response to atmosphere and, thusly, to the variability and global climate change (Bockheim, 1995, Bockheim et al., 2008). An understanding of the distribution and properties of Antarctic permafrost is essential not only for the cryospheric sciences but also for the life sciences, since it will be a major effect ecosystem modification following climate-induced changes and variability (Vieira et. al., 2010). 


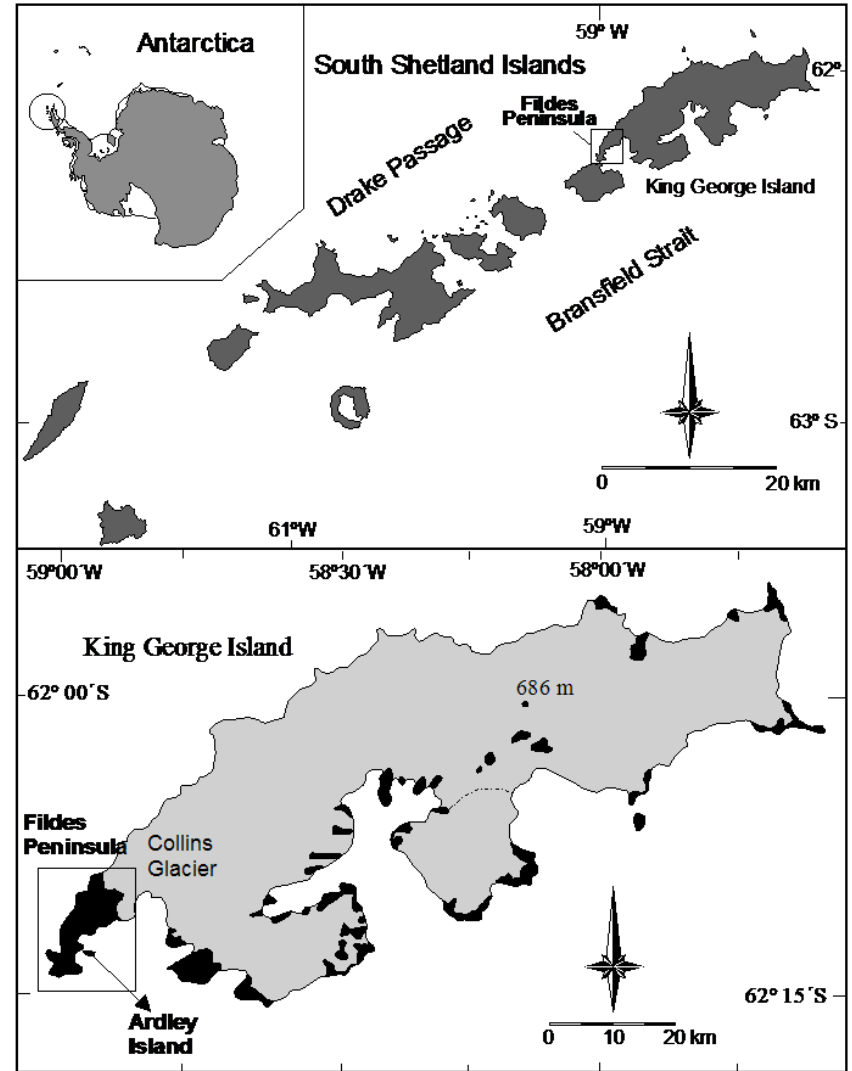

Figure 1. Location of Fildes Peninsula within Antarctica and the South Shetland Islands.

The scientific interest in King George Island has grown in the last few years due to the intensity of climate change effects such as permafrost degradation (Beyer et al., 1999).

The objective of this paper is to present active-layer temperature data for one CALM-S site located on the Fildes Peninsula, King George Island, maritime Antarctica over a 57-month period (2008-2012).

\section{Material and methods}

\subsection{Studied site}

The archipelago of the South Shetland Islands, extending more than $400 \mathrm{~km}$ from southwest to northeast, lies near the northern tip of the Antarctic Peninsula. The archipelago is separated from the Antarctic Peninsula by the Bransfield Strait and from South America by Drake Passage. King George Island is the largest in the archipelago and Fildes Peninsula is at its southwestern end (Fig. 1). This peninsula is about $10 \mathrm{~km}$ long and $2-4 \mathrm{~km}$ wide. It is washed on three sides by the waters of Drake Passage, Fildes Strait and Maxwell Bay. Most of the Fildes Peninsula is free of ice; glaciers cover only the extreme northeastern part (Simonov, 1975). Fildes Peninsula has a gentle topography dominated by a wide central plain, and several other plains CE5 at different altitudes; it consists mostly of lava with small outcrops of tuffs, volcanic sandstones and agglomerates (Smellie et al., 1984).

The region experiences a subantarctic maritime climate according to the Köppen climate classification. The South Shetland Islands have an ET (tundra climate) climate, South Hemispheric Polar Oceanic (Köppen, 1936), characterized by mean annual air temperatures of $-2.2{ }^{\circ} \mathrm{C}$ (data from 2000 through 2012 from the Marsh meteorological station at $-62^{\circ} 11^{\prime} 27^{\prime \prime} \mathrm{S}, 58^{\circ} 59^{\prime} 12^{\prime \prime} \mathrm{W}$ and $10 \mathrm{~m}$ of altitude) and mean summer air temperatures above $0{ }^{\circ} \mathrm{C}$ lasting up to 4 months (Rakusa-Suszczewski et al., 1993; Wen et al., 1994). Precipitation ranges between 350 and $500 \mathrm{~mm}$ per year with rainfall occurring in the summer period (Øvstedal and Lewis-Smith, 2001). Ferron et al. (2004) found great climate variability when analyzing data from 1947 to 1995 and identified cycles of 5.3 years of colder conditions followed by 9.6 years of warmer conditions.

Soils in Fildes Peninsula are well developed for Antarctic standards with large areas of soils with Leptic/Lithic and Skeletic characters. Arenosols/Entisols and Cryosols/Gelisols (frequently turbated) are the most important soil classes, while Leptosols/Entisols, Gleysols/Aquents and Cambisols/Inceptisols also occur with gelic regime. Faunal activity plays a marked role in soil genesis on Fildes Peninsula and is commonly found in the north shore of the peninsula. The dominant soils are Cryosols, related to cryoturbation and active-layer processes and developed on wide areas occupied by stone fields, patterned grounds, moraines and slopes on middle and upper platforms and hills in the northern and southern areas (Michel et al., 2014).

\subsection{Methods}

The active-layer monitoring site $\left(-62^{\circ} 12^{\prime} 12^{\prime \prime} \mathrm{S}\right.$, $58^{\circ} 57^{\prime} 37^{\prime \prime} \mathrm{W}$ at $60 \mathrm{~m}$ of altitude) was installed in the summer of 2008 and consists of thermistors (accuracy $\pm 0.2^{\circ} \mathrm{C}$ ) (model 107 Temperature Probe, Campbell Scientific Inc, Utah, USA) arranged in a vertical array at different depths down to the permafrost table $(10.5 \mathrm{~cm}(\mathrm{~F} 1), 32.5 \mathrm{~cm}$ (F2), $67.5 \mathrm{~cm}(\mathrm{~F} 3), 83.5 \mathrm{~cm}(\mathrm{~F} 4))$. The site was selected during a soil survey and represents most of Turbic Cryosols occurring on the peninsula. All probes were connected to a data logger (model CR 1000, Campbell Scientific Inc, Utah, USA) recording data at hourly intervals from 1 March 2008 until 30 November 2012.

The characteristics of the monitored site and the exact depth of the probes are presented in Tables 1 and 2. The depth of the probes was established in respect to pedological differentiation of horizons. Sites affected by cryoturbation frequently form $\mathrm{AB}$ horizons; the intense migration of the organic material in depth associated with the limited carbon input (mosses and lichens) makes the formation of $\mathrm{A}$ horizons difficult. Air temperature was obtained from the 
Table 1. General characteristics of the monitored site.

\begin{tabular}{|c|c|c|c|c|c|}
\hline Site & Altitude/slope/aspect & $\begin{array}{l}\text { Soil class } \\
\text { WRB/soil } \\
\text { taxonomy }\end{array}$ & Vegetation cover & ALT $^{*}$ & $\begin{array}{l}\text { Thermistor } \\
\text { depth }\end{array}$ \\
\hline Fildes & $65 \mathrm{~m} / 3 \% \max . / S$ & $\begin{array}{l}\text { Turbic Cryosol } \\
\text { (Eutric)/Aquic } \\
\text { Haploturbels }\end{array}$ & $\begin{array}{l}\text { Mosses and lichens } \\
\text { (Usnea sp. and } \\
\text { Himantormia sp.) }\end{array}$ & $\begin{array}{l}102.5 \mathrm{~cm} \\
(2008) ; \\
117.5(2009) ; \\
90.2 \mathrm{~cm} \\
(2010) ; \\
105.8 \mathrm{~cm} \\
(2011) \\
89.0 \mathrm{~cm}(2012) ;\end{array}$ & $\begin{array}{l}10.5 \mathrm{~cm}(\mathrm{~F} 1), \\
32.5 \mathrm{~cm}(\mathrm{~F} 2), \\
67.5 \mathrm{~cm}(\mathrm{~F} 3), \\
83.5 \mathrm{~cm}(\mathrm{~F} 4)\end{array}$ \\
\hline
\end{tabular}

* ALT - active-layer thickness

Table 2. Soil texture of the studied profile.

\begin{tabular}{lrrrrrr}
\hline $\begin{array}{l}\text { Depth } \\
(\mathrm{cm})\end{array}$ & $\begin{array}{r}\mathrm{CS}^{\mathrm{a}} \\
\mathrm{g} \mathrm{kg}^{-1}\end{array}$ & $\mathrm{FS}^{\mathrm{b}}$ & Silt $^{\mathrm{c}}$ & Clay $^{\mathrm{d}}$ & Class & $\mathrm{CSF}^{\mathrm{e}}$ \\
\hline \multicolumn{7}{l}{ Fildes - Turbic Haplic Cryosol (Eutric) } \\
AB 0-20 & 28 & 18 & 34 & 20 & Loam & 13 \\
B 20-50 & 29 & 17 & 36 & 18 & Loam & 16 \\
C 50-100 & 14 & 30 & 47 & 9 & Loam & 19 \\
\hline
\end{tabular}

${ }^{\mathrm{a}}$ Coarse sand $(0.2 \leq 2 \mathrm{~mm}),{ }^{\mathrm{b}}$ Fine sand $(0.05 \leq 0.2 \mathrm{~mm}),{ }^{\mathrm{c}} 0.002 \leq 0.05 \mathrm{~mm},{ }^{\mathrm{d}}$ $<0.002 \mathrm{~mm},{ }^{\mathrm{e}}$ Coarse fraction of soil $(>2 \mathrm{~mm})$.

Marsh automatic meteorological station located at the Teniente Rodolfo Marsh Martin Airport.

We calculated the thawing days (days in which all hourly soil temperature measurements are positive and at least one reading is warmer than $+0.5^{\circ} \mathrm{C}$ ), freezing days (days in which all hourly soil temperature measurements are negative and at least one reading is colder than $-0.5^{\circ} \mathrm{C}$ ), isothermal days (days in which all the hourly measurements range only between $\pm 0.5^{\circ} \mathrm{C}$ ), freeze-thaw days (days in which there are both negative and positive temperatures with at least one value greater than $\pm 0.5^{\circ} \mathrm{C}$ ), thawing degree days (TDD, obtained by the cumulative sum of the mean daily temperatures above $0{ }^{\circ} \mathrm{C}$ ) and freezing degree days (FDD, obtained by the cumulative sum of the mean daily temperatures below $0{ }^{\circ} \mathrm{C}$ ) according to Guglielmin et al. (2008). The active-layer thickness (ALT) was calculated as the $0{ }^{\circ} \mathrm{C}$ depth by extrapolating the thermal gradient from the two deepest temperature measurements (Guglielmin, 2006).

The apparent thermal diffusivity (ATD) was estimated for different seasons from the equation of McGaw et al. (1978):

$$
\begin{aligned}
& \alpha=\left[\Delta Z^{2} / 2 \Delta t\right] \times\left[\left(T_{i}^{j+1}-T_{i}^{j-1}\right) /\right. \\
& \left.\left(T j i^{-1}-2 T_{j}^{i}+T_{j}^{i+1}\right)\right]
\end{aligned}
$$

where $\alpha$ is the apparent thermal diffusivity $\left(\mathrm{m}^{2} \mathrm{~s}^{-1}\right), \Delta t$ is time increments (s), $\Delta Z$ is space increments (m), $T$ is the temperature, $j$ is the temporal position and $i$ is the depth position.

Nelson et al. (1985), Outcalt and Hinkel (1989) and Hinkel et al. $(1990,2001)$ have used this estimative to assess the resistance to energy flux in the profile. Hourly estimations were made for intermediate depths of both profiles, and mean values were calculated and plotted for each day.

A series of statistical analyses were performed to describe the soil temperature time series. The Box-Pierce test and augmented Dickey-Fuller tests where performed to confirm the stationarity and independent distribution of the time series (data not shown). The histogram (frequency distribution of temperature readings) and first difference (the difference between consecutive hourly temperature readings) were plotted, and the time series was decomposed into its seasonal and trend components by locally weighted smoothing (Loess) using a window of 25. A linear fit was applied to the time series in order to identify a global trend. Finally, a series of autoregressive integrated moving average (ARIMA) models were tested until satisfactory results were found. In order to define the best fit for the data, we first examined the ACF (Auto correlation function) and PACF (Partial Auto correlation function) plots to determine the appropriate model and then tested a series of combinations; standardized residuals, autocorrelation plot, Ljung-Box statistics and the Akaike information criterion (AIC) (Burnham and Anderson, 2002) were the major parameters used to judge the suitability of the model. Considering the seasonal nature of the data, a seasonal component was added after the best models were selected.

For a time series of data $x_{\mathrm{t}}$, where $t$ is time and $x$ is the real number (soil temperature in the present case), an ARMA ( $q$, $p^{\prime}$ ) model is used:

$\left(1-\sum_{i=1}^{p^{\prime}} \Phi_{i} L^{i}\right) x_{\mathrm{t}}=\left(1+\sum_{i=1}^{q} \theta_{i} L^{i}\right) \varepsilon_{\mathrm{t}}$,

where $p^{\prime}$ is autoregressive terms, $q$ is moving-average terms, $L$ is the lag operator, $\varphi$ is the autoregressive parameter, $\theta$ is 
the moving average parameter, $\varepsilon$ is the error and $i$ is the $i$ th term. The errors are assumed to be independent, identically distributed variables sampled from a normal distribution with zero mean and one standard deviation $[0,1]$.

When the term $\left(1-\sum_{i=1}^{p^{\prime}} \Phi_{i} L^{i}\right)$ has a unitary root of multiplicity $d$, it can be rewritten as

$$
\left(1-\sum_{i=1}^{p^{\prime}} \Phi_{i} L^{i}\right)=\left(1-\sum_{i=1}^{p^{\prime}-q} \Phi_{i} L^{i}\right)(1-L)^{d} .
$$

An ARIMA $(p, d, q)$ model expresses this polynomial factorization property with $p=p^{\prime}-d$ and is expressed by

$$
\left(1-\sum_{i=1}^{p} \Phi_{i} L^{i}\right)(1-L)^{d} x_{\mathrm{t}}=\left(1+\sum_{i=1}^{q} \theta_{i} L^{i}\right) \varepsilon_{\mathrm{t}}
$$

and thus can be thought of as a particular case of an ARMA $(p+d, q)$ process with an autoregressive polynomial with $d$ unit roots.

\section{Results and discussion}

Interannual variability of the active-layer temperature shows parallel behavior despite contrasts between different years; daily temperatures records are presented in Fig. 2. The temperature at $10.5 \mathrm{~cm}$ reaches a maximum daily average $\left(4.1^{\circ} \mathrm{C} \pm 0.5\right)$ in early January and a minimum $\left(-8.0^{\circ} \mathrm{C} \pm 1.4\right)$ between late July and early August. At $83.5 \mathrm{~cm}$ the maximum temperature $\left(0.3^{\circ} \mathrm{C} \pm 0.2\right)$ occurs in late March and the minimum reading $\left(-4.1^{\circ} \mathrm{C} \pm 1.0\right)$ around mid-August. Disparities can be noticed when comparing the different years: 2008 had a mild winter (21 freezing days and -1 freezing degree days at $83.5 \mathrm{~cm}$ in July) contrasted by a severe winter in 2011 ( 31 freezing days and -80 freezing degree days at $83.5 \mathrm{~cm}$ in July), whereas the summer of 2009 was considerably warmer (31 thawing days and 65 thawing degree days at $10.5 \mathrm{~cm}$ in January) compared to the summer of 2010 (17 thawing days and 21 thawing degree days at $10.5 \mathrm{~cm}$ in January). Daily air temperatures on Fildes Peninsula over the studied period averaged $-2.3^{\circ} \mathrm{C}( \pm 4.1)$, reaching a maximum and a minimum of 5.8 and $-21.2^{\circ} \mathrm{C}$ in early January and late June, respectively. The difference between maximum and minimum daily averages was greater for 2009 and 2011; in these years, more extreme minimum temperatures were recorded $\left(-17.4^{\circ} \mathrm{C}\right.$ for 2009 and $-18.6{ }^{\circ} \mathrm{C}$ for 2011). The freezing season started in late May and the thawing season in mid-December with small variability between the years. Soil temperature averaged $-1.2{ }^{\circ} \mathrm{C}$ (av max $2.1^{\circ} \mathrm{C}$ and av $\min -7.3^{\circ} \mathrm{C}$ ) over all layers: using hourly measurements, maximum soil temperature for the upper-most layer (F1) was $8.7^{\circ} \mathrm{C}$ and the minimum temperatures were -9.8 , 0.5 and $-5.4^{\circ} \mathrm{C}$ at the bottom-most layer (F4).
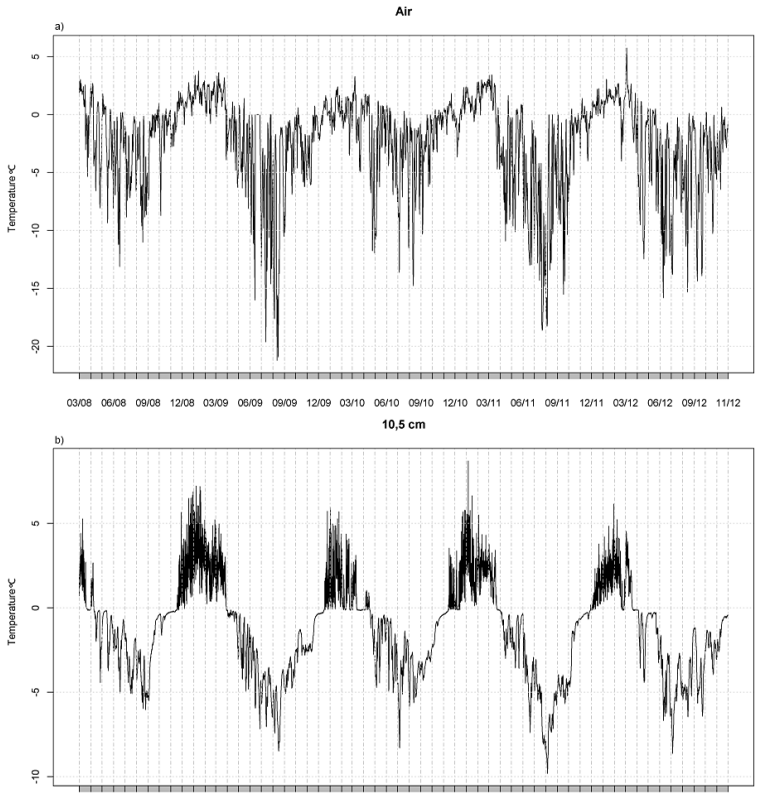

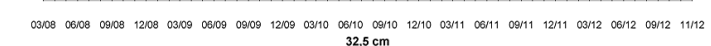
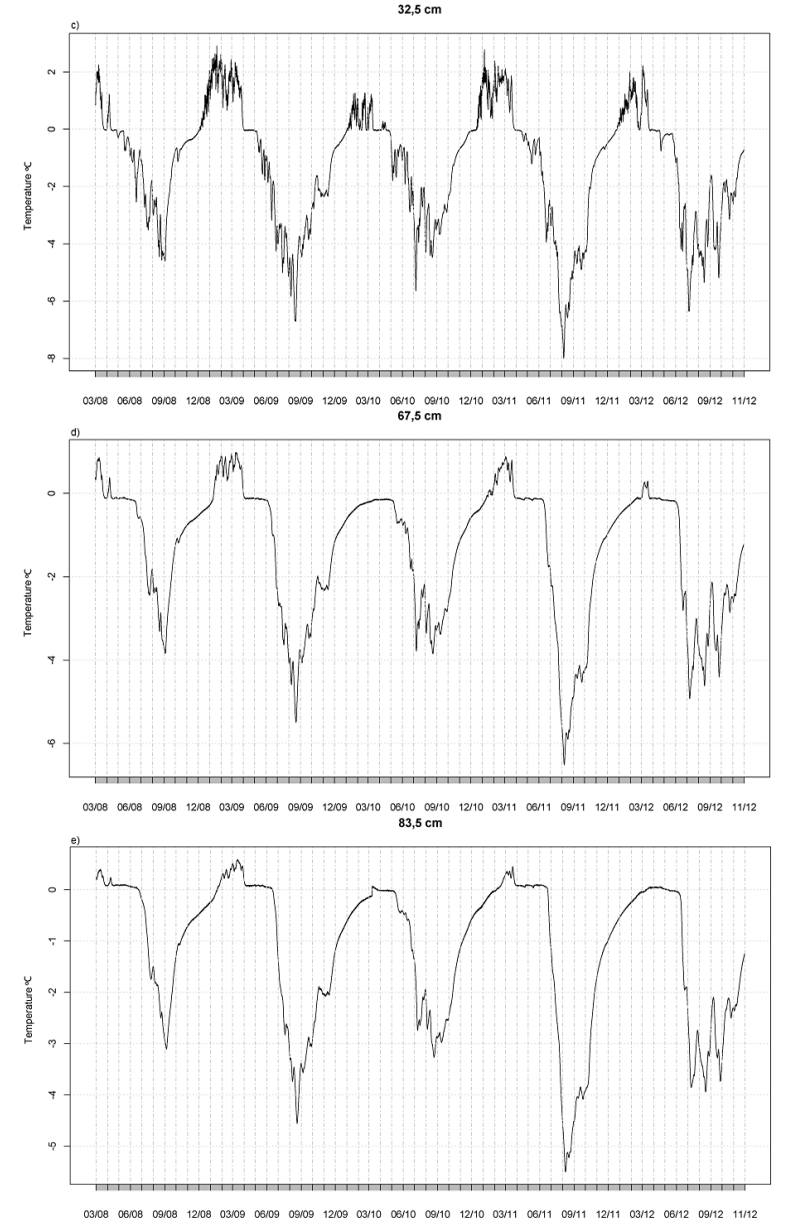

Figure 2. Daily temperatures records for air (a), F1 (b), F2 (c), F3 (d) and F4 (e). 

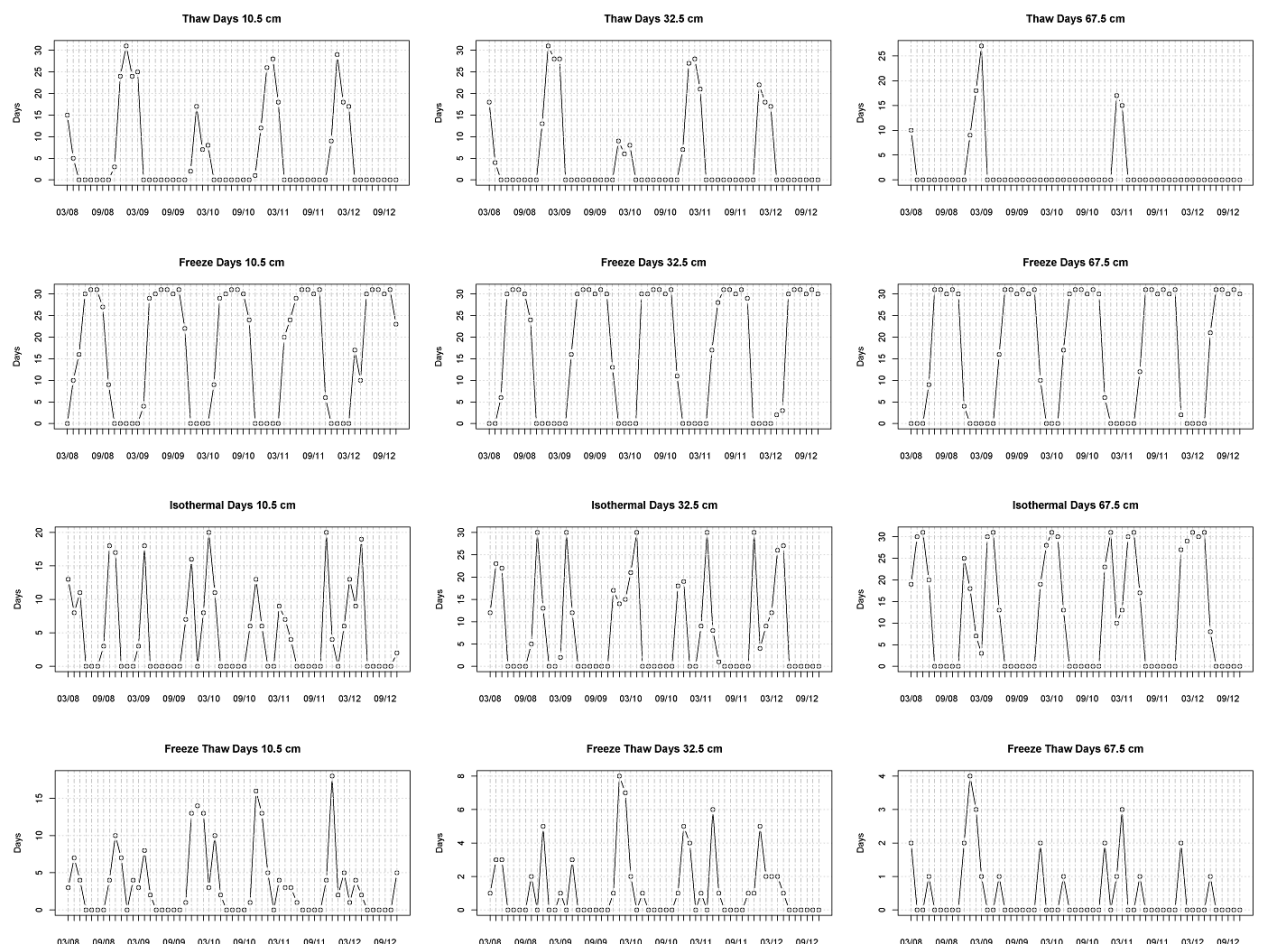

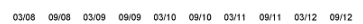

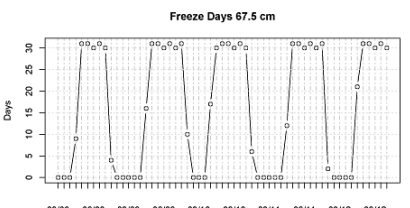

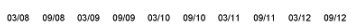
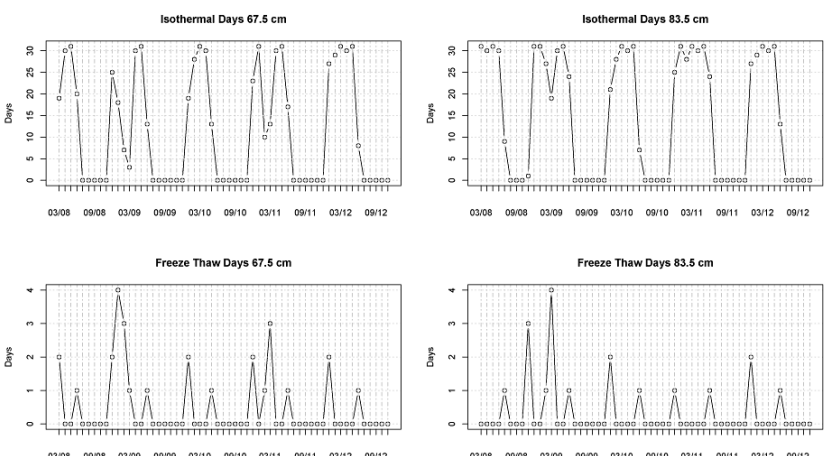

Figure 3. Thaw days, freeze days, isothermal days and freeze-thaw days for F1, F2, F3 and F4.

ALT was estimated for every season and the results are summarized in Table 1 (2008 and 2012 being incomplete). Maximum ALT ranged between 89 and $106 \mathrm{~cm}$ with a mean of $101 \mathrm{~cm}$; the totality of the active layer froze during winter every year over the studied period. During 2010 a curious phenomenon occurred: temperatures at $\mathrm{F} 3$ remained negative the whole year, reaching values above zero at the bottommost layer (F4); that year ATL was estimated slightly below the deepest probe, probably due to the accumulation of water over the permafrost table.

The grouping of days into freezing, thawing, isothermal and freeze-thaw offers a quick parameter for comparing different periods (Fig. 3). Most of the thawing days occurred between January and March, more frequently for the uppermost layers; only 8 days were recorded for F4 in March 2009. Freeze days were concentrated between April and November and are more evenly distributed in depth although F1 and F2 were frozen for longer periods in 2008, 2011 and 2012. Isothermal and freeze-thaw days occurred between December and May. Isothermal periods were long for F3 and F4, which shows a strong zero curtain effect (buffered temperature change due to freezing and thawing of soil moisture). Freeze-thaw days were more common in F1; the site experienced frequent freeze-thaw cycles in the surface, especially during summer. Great temperature changes in depth, especially on the -0.5 to $0.5^{\circ} \mathrm{C}$ zone, were rare; only 1 day was recorded in 2011 for $\mathrm{F} 4$.
The cumulative sum of the daily averages reached a maximum in 2009 and a minimum in 2011 for all layers; values varied greatly over the years, with December and January being the hottest months and June always the coldest (Fig. 4). Over the 57 months, the TDD were $902{ }^{\circ} \mathrm{C}$ day $(\mathrm{F} 1), 449^{\circ} \mathrm{C}$ day (F2), $96^{\circ} \mathrm{C}$ day (F3) and $64^{\circ} \mathrm{C}$ day (F4). The FDD were $-3229^{\circ} \mathrm{C}$ day $(\mathrm{F} 1),-2623{ }^{\circ} \mathrm{C}$ day $(\mathrm{F} 2),-2433{ }^{\circ} \mathrm{C}$ day $(\mathrm{F} 3)$ and $-2040^{\circ} \mathrm{C}$ day $(\mathrm{F} 4)$. Contrast between different years was significant: in $2011 \mathrm{FDD}$ accumulated $-819^{\circ} \mathrm{C}$ day in the surface and $-516^{\circ} \mathrm{C}$ day at $\mathrm{F} 4$; in contrast, 2011 accumulated $-527^{\circ} \mathrm{C}$ in the surface and $-382{ }^{\circ} \mathrm{C}$ at $\mathrm{F} 4$. There was a clear preponderance of negative soil temperatures in the studied profile; despite the percolation of liquid water and above-freezing temperatures during the summer, positive temperatures were mild in the soil profile.

ATD was calculated for F3 and F4 by considering hourly readings and then averaging for the climatic seasons; results are shown in Table 3. Thermal diffusivity can experience considerable seasonal variations when thawing and freezing processes occur (Hinkel, 1997). The ability of the profile to transmit energy varies during the year due mostly to water content: moisture, on the one hand, enhances energy flux through percolation but, on the other hand, absorbs and emits energy on freezing and thawing processes. Average ATD for the 57 months was $4.2 \times 10^{-5}$ (F2) and $1.1 \times 10^{-5} \mathrm{~m}^{2} \mathrm{~s}^{-1}(\mathrm{~F} 3)$; these values are consistent with other findings from wet soil profiles of maritime Antarctica. De Pablo et. al. (2013) found values of $4.7 \pm 0.7 \times 10^{-7}$ 


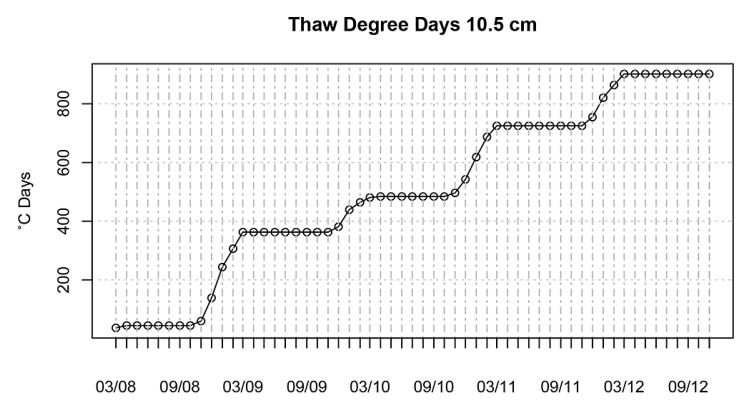

Thaw Degree Days $32.5 \mathrm{~cm}$

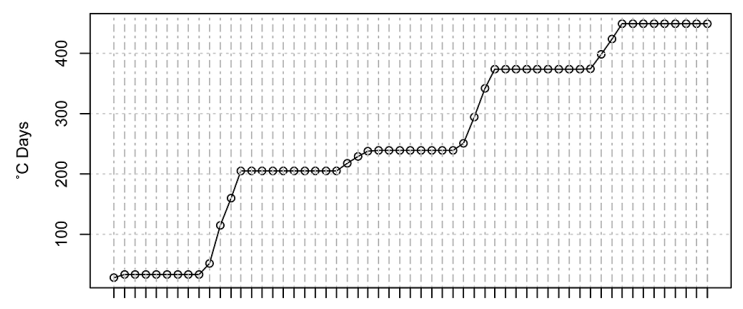

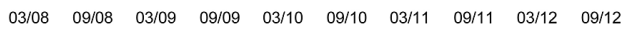

Thaw Degree Days $67.5 \mathrm{~cm}$

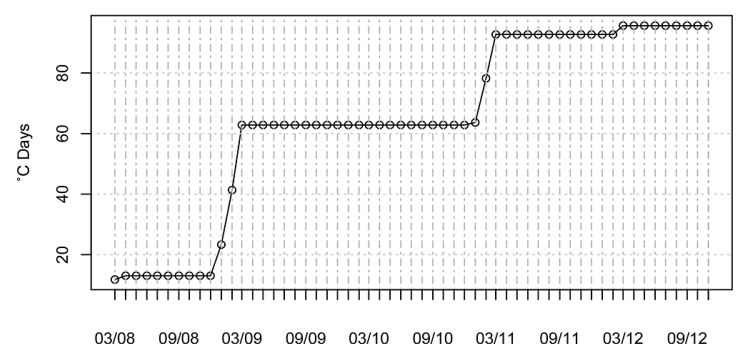

Thaw Degree Days $83.5 \mathrm{~cm}$

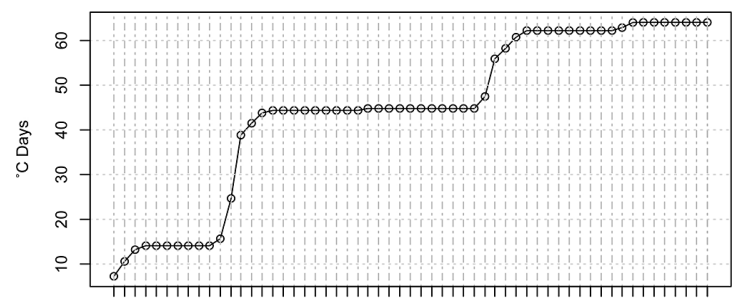

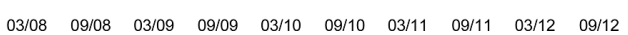

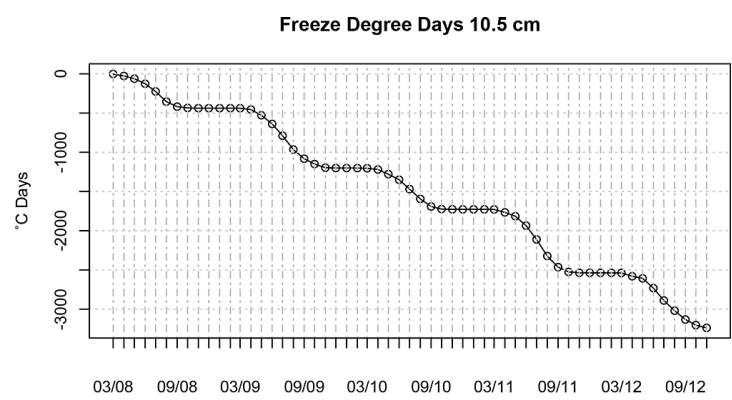

Freeze Degree Days $32.5 \mathrm{~cm}$

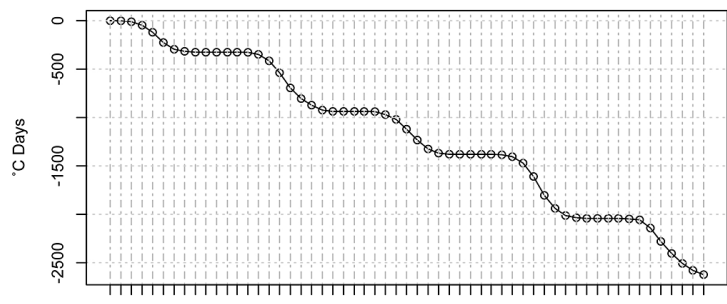

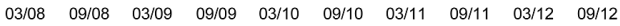

Freeze Degree Days $67.5 \mathrm{~cm}$

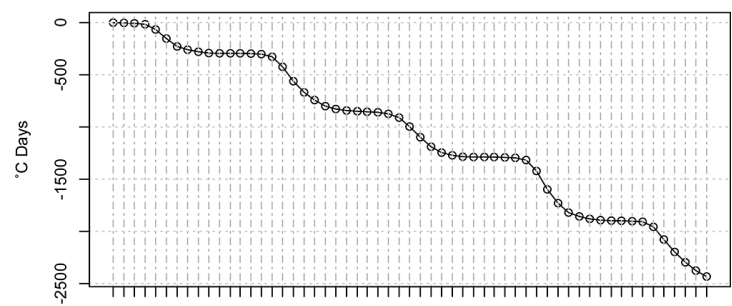

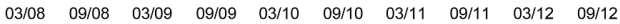

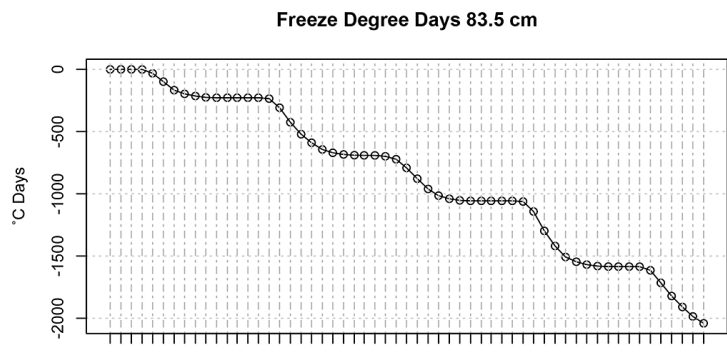

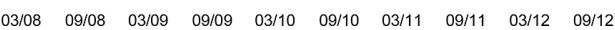

Figure 4. Thaw degree days and freeze degree days for F1, F2, F3 and F4.

and $5.3 \pm 1.8 \times 10^{-7} \mathrm{~m}^{2} \mathrm{~s}^{-1}$ for the summer period in a profile from Byers Peninsula, Livingstone Island. ATD calculated for F2 has a tendency towards smaller values in winter: they were negative for fall and winter of 2009, when an abnormally cold winter occurred and the thaw season was reduced at $32.5 \mathrm{~cm}$. F3 values are consistently smaller due to its proximity to the permafrost table: negative values were more common, occurring in winter and spring of 2008, fall and winter of 2009 and winter of 2010 and 2011. This behavior indicates temperature buffering capacity: negative ATD values suggest that nonconductive effects oppose and overwhelm the conductive trend (Outcalt and Hinkel, 1989).

Histograms for the studied layers show a predominance of temperatures around $0 . \mathrm{F} 3$ expresses the largest frequency in this region while the greatest amplitude is found for F1 $\left(15^{\circ} \mathrm{C}\right)$ (Fig. 5). The plot of first differences of the hourly measurements gives us an idea of periods with great temperature oscillation. Most of the strong variations are associated with summer for F1 and F2 while being evenly distributed for F3 and very limited for F4 (Fig. 5). The decomposition 

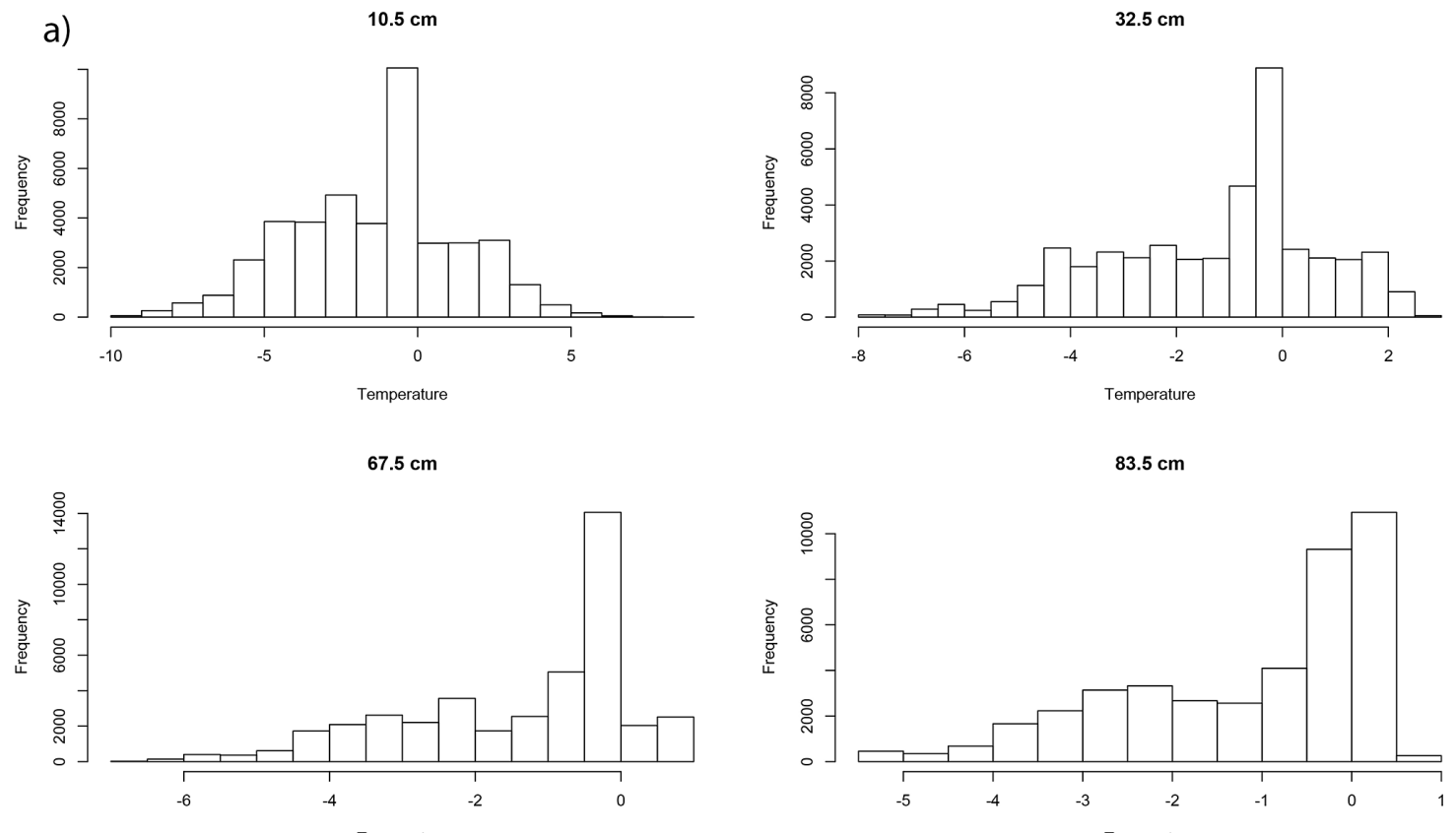

b) Temperature
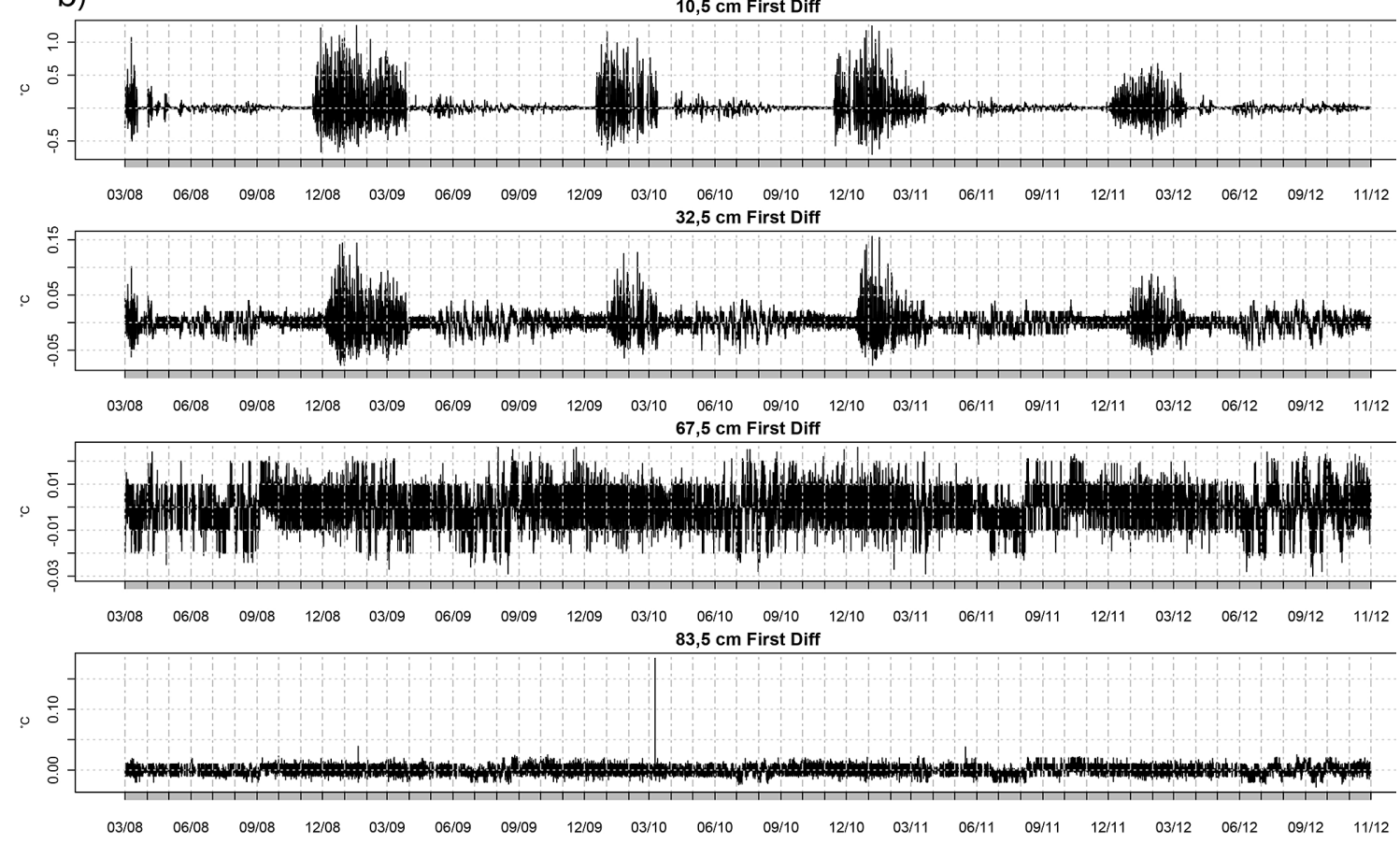

Figure 5. Histograms and first differences for F1, F2, F3 and F4.

of the time series reveals a great seasonal component associated with summer for F1 and F2, with most of the noise also concentrated in the warmer months. F3 behaves more erratically, and the seasonal effect at F4 is shifted ahead, while noise is reduced (Fig. 6). Linear regression was performed on hourly readings in order to have an estimation of overall trend: the slope of the line is slightly negative for all layers and intercept is always negative (Fig. 7).
Although the studied period was limited to 57 months and any forecast is not suitable, an ARIMA model was tested at each layer in order to evaluate which model better fit the data. Autocorrelation and partial autocorrelation plots were estimated as a guide for the selection of the ARIMA parameters. The plots (Fig. 8) show strong correlation with data from the previous month. This correlation is smaller for the subsequent period and, after the fourth month, starts to show 

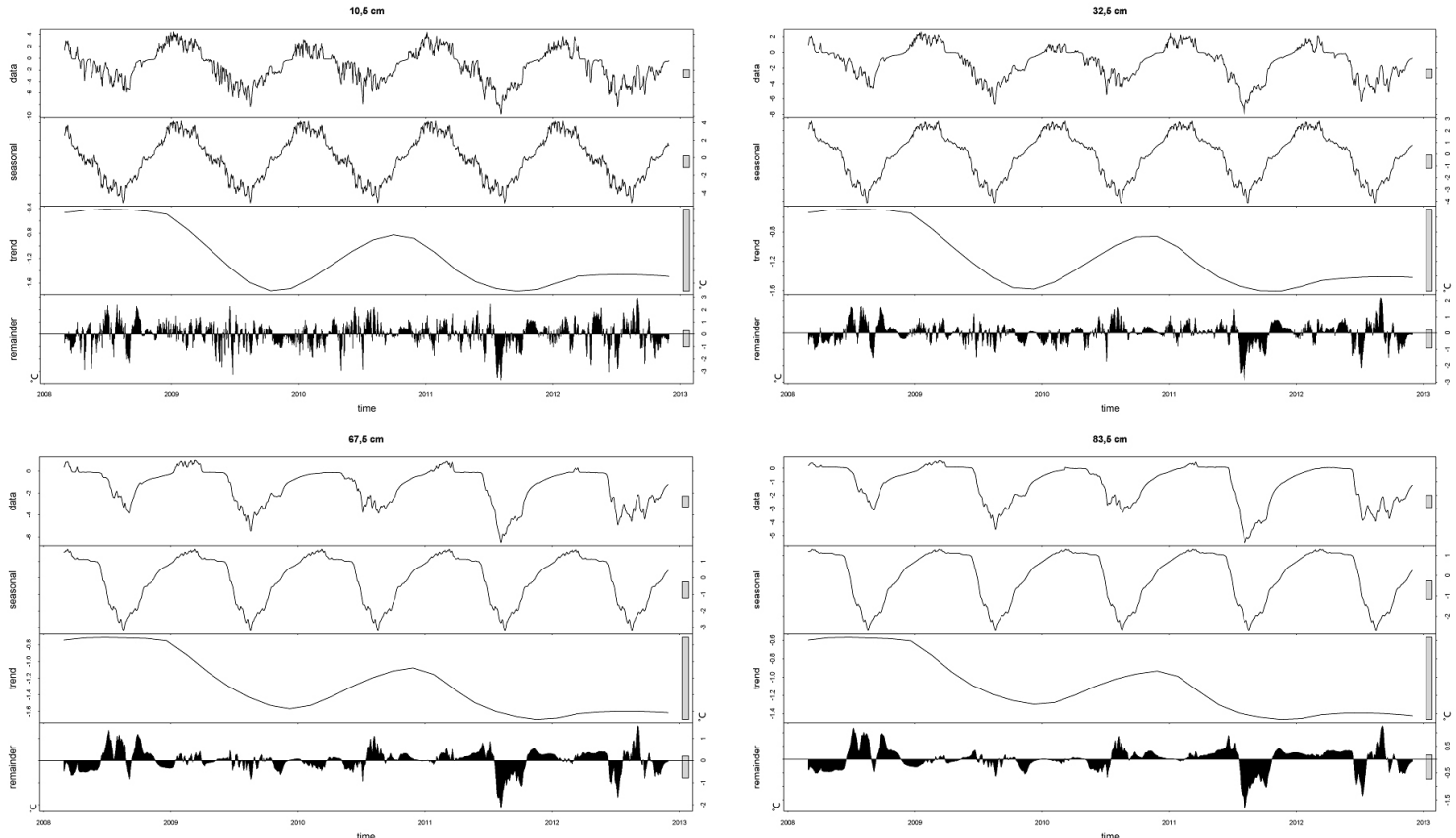

Figure 6. Loess time series decomposition for F1, F2, F3 and F4.

Table 3. Average season temperatures $\left({ }^{\circ} \mathrm{C}\right)$ for air, F1, F2, F3 and F4; ATD $\left(\mathrm{m}^{2} \mathrm{~s}^{-1}\right)$ for F2 and F3.

\begin{tabular}{lrrrrrrr}
\hline Averages & Air & F1 & F2 & F3 & F4 & ATD_F2 & ATD_F3 \\
\hline Fall 2008 & -2.4 & -1.1 & -0.3 & -0.1 & 0.1 & $1.4 \mathrm{E}-04$ & $6.3 \mathrm{E}-05$ \\
Winter 2008 & -3.5 & -3.2 & -2.7 & -2.2 & -1.6 & $1.0 \mathrm{E}-05$ & $-3.4 \mathrm{E}-06$ \\
Spring 2008 & -0.3 & 0.4 & -0.4 & -0.8 & -0.8 & $1.3 \mathrm{E}-04$ & $-8.8 \mathrm{E}-06$ \\
Summer 2009 & 1.6 & 2.6 & 1.6 & 0.4 & 0.1 & $3.5 \mathrm{E}-05$ & $2.6 \mathrm{E}-07$ \\
Fall 2009 & -2.5 & -1.5 & -0.5 & -0.1 & 0.1 & $-1.9 \mathrm{E}-04$ & $-1.3 \mathrm{E}-05$ \\
Winter 2009 & -6.4 & -5.0 & -4.2 & -3.5 & -2.9 & $-9.3 \mathrm{E}-07$ & $-4.0 \mathrm{E}-06$ \\
Spring 2009 & -2.0 & -1.7 & -1.8 & -2.0 & -1.9 & $1.1 \mathrm{E}-05$ & $1.1 \mathrm{E}-05$ \\
Summer 2010 & 0.4 & 1.4 & 0.5 & -0.3 & -0.3 & $2.3 \mathrm{E}-04$ & $5.9 \mathrm{E}-06$ \\
Fall 2010 & -2.2 & -1.3 & -0.6 & -0.4 & -0.2 & $1.5 \mathrm{E}-04$ & $1.6 \mathrm{E}-05$ \\
Winter 2010 & -4.1 & -3.7 & -3.3 & -2.9 & -2.5 & $8.4 \mathrm{E}-06$ & $-1.0 \mathrm{E}-06$ \\
Spring 2010 & -0.6 & -0.4 & -0.9 & -1.3 & -1.2 & $2.9 \mathrm{E}-05$ & $2.9 \mathrm{E}-05$ \\
Summer 2011 & 1.6 & 2.2 & 1.3 & 0.2 & 0.0 & $2.9 \mathrm{E}-05$ & $1.9 \mathrm{E}-06$ \\
Fall 2011 & -4.3 & -1.8 & -0.6 & -0.1 & 0.1 & $8.6 \mathrm{E}-05$ & $2.9 \mathrm{E}-05$ \\
Winter 2011 & -7.9 & -5.7 & -4.9 & -4.2 & -3.5 & $4.8 \mathrm{E}-08$ & $-5.9 \mathrm{E}-06$ \\
Spring 2011 & -1.2 & -1.1 & -1.6 & -2.0 & -2.0 & $6.3 \mathrm{E}-06$ & $1.6 \mathrm{E}-05$ \\
Summer 2012 & 1.4 & 1.9 & 0.9 & -0.2 & -0.2 & $4.4 \mathrm{E}-05$ & $5.0 \mathrm{E}-05$ \\
Fall 2012 & -3.9 & -1.7 & -0.7 & -0.4 & -0.1 & $1.0 \mathrm{E}-06$ & $1.1 \mathrm{E}-05$ \\
Winter 2012 & -5.5 & -4.3 & -3.9 & -3.6 & -3.0 & $6.8 \mathrm{E}-06$ & $7.3 \mathrm{E}-07$ \\
Spring 2012 & -3.1 & -2.1 & -2.2 & -2.5 & -2.3 & $3.4 \mathrm{E}-05$ & $1.2 \mathrm{E}-05$ \\
\hline AVG & -2.2 & -1.2 & -1.1 & -1.3 & -1.1 & $4.2 \mathrm{E}-05$ & $1.1 \mathrm{E}-05$ \\
Standard deviation & 2.8 & 2.5 & 1.9 & 1.5 & 1.3 & $8.3 \mathrm{E}-05$ & $1.9 \mathrm{E}-05$ \\
& & & & & & & \\
\hline & & & & & & & \\
& & & & & & &
\end{tabular}

increasing negative correlation, reaching a maximum at the seventh month. After 3 years, significant correlation can still be seen. Partial autocorrelations express a "cleaner" picture of serial dependencies for individual lags. The plot shows a strong correlation for the previous month, which is negative for the subsequent period and not significant after the fifth lag. The best ARIMA model that fits the monthly averages includes a seasonal component; $p, d$ and $q$ factors for the 

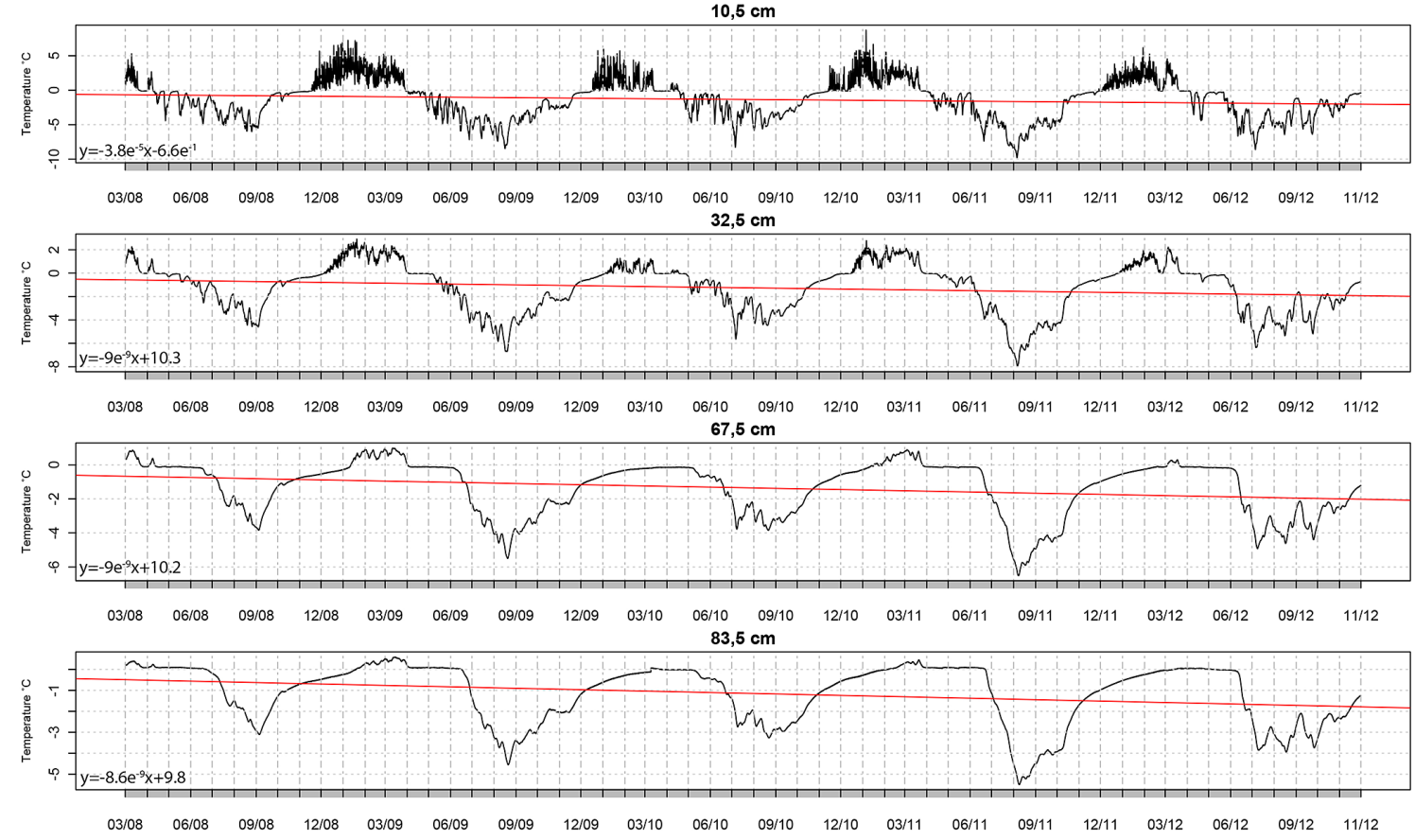

Figure 7. Linear regression for F1, F2, F3 and F4.

Table 4. ARIMA order, coefficients sigma squared and log of likelihood for F1, F2, F3, and F4.

\begin{tabular}{|c|c|c|c|c|}
\hline ARIMA & F1 & $\mathrm{F} 2$ & F3 & F4 \\
\hline Order (seasonal) & $(1,0,0)(1,1,0)$ & $(0,0,0)(1,1,0)$ & $(1,0,0)(1,1,0)$ & $(1,0,2)(2,0,0)$ \\
\hline Coefficients & $\begin{array}{l}\text { ar1 } 0.2540 \\
\text { sar1 }-0.5507\end{array}$ & $\begin{array}{l}\text { ar1 } 0.2568 \\
\text { sar1 }-0.7355\end{array}$ & $\begin{array}{l}\operatorname{ar} 10.3534 \\
\text { sar1 }-0.7224\end{array}$ & $\begin{array}{l}\text { ar1 } 0.5030 \\
\text { ma1 } 0.2355 \\
\text { ma2 }-0.0322 \\
\text { sar1 } 00.2536 \\
\text { sar2 } 0.6152\end{array}$ \\
\hline Sigma $^{2}$ & 2.17 & 0.85 & 0.44 & 0.25 \\
\hline log likelihood & -83.53 & -64.91 & -50.01 & -50.88 \\
\hline $\mathrm{AICc}$ & 173.65 & 136.41 & 106.6 & 118.06 \\
\hline BIC & 178.49 & 141.25 & 111.44 & 130.07 \\
\hline
\end{tabular}

model and its seasonal component are always small or null, as indicated by the partial autocorrelations. The best model for F1 and F3 includes one autoregressive parameter, one seasonal autoregressive parameter and one seasonal differentiating parameter (Table 4). The best model for F2 includes only seasonal parameter, one seasonal autoregressive parameter and one seasonal differentiating parameter. The best fit for F4 includes one autoregressive parameter, two moving average parameters and two seasonal autoregressive parameters. The diagnostics of the models (Fig. 9) are satisfactory, the standardized residuals do not show clusters of volatility, no significant auto correlation is found between the residuals and the $\rho$ values for the Ljung-Box statistics are all large, indicating that the residuals are pattern-less. 


\section{Conclusions}

Monitoring of the CALM-S site on Fildes Peninsula has provided data on the thermal dynamics and frost conditions on a densely occupied maritime Antarctic site. The effects of weather on the thermal regime of the active layer have been identified, providing insights into the influence of climate change on permafrost and leading to the following conclusions:

- The active-layer thermal regime in the studied period was typical of periglacial environments, with extreme variation in surface temperature during summer resulting in frequent freeze and thaw cycles.

- The ALT over the studied period shows a degree of variability related to different annual weather conditions, reaching a maximum of $117.5 \mathrm{~cm}$ in 2009 .

- The calculated ATD suggests strong influence of water content on the soil thermal regime.

- The ARIMA model can describe the data adequately and is an important tool for more conclusive analysis and predictions when longer data sets are available.

- Despite the variability when comparing temperature readings and ACT over the studied period, no trend can be identified. 

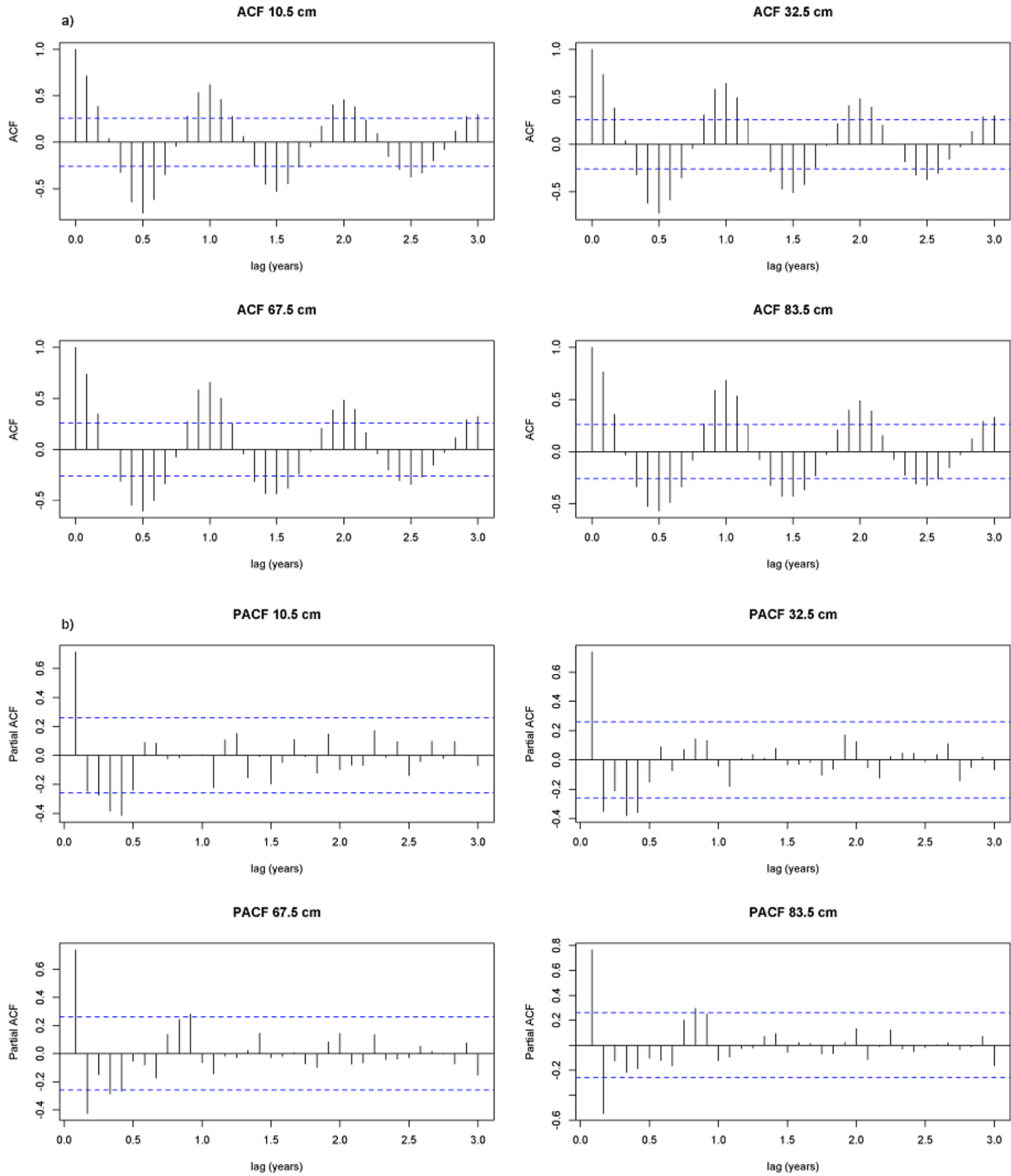

Figure 8. Autocorrelation and partial autocorrelation plots for F1, F2, F3 and F4. 

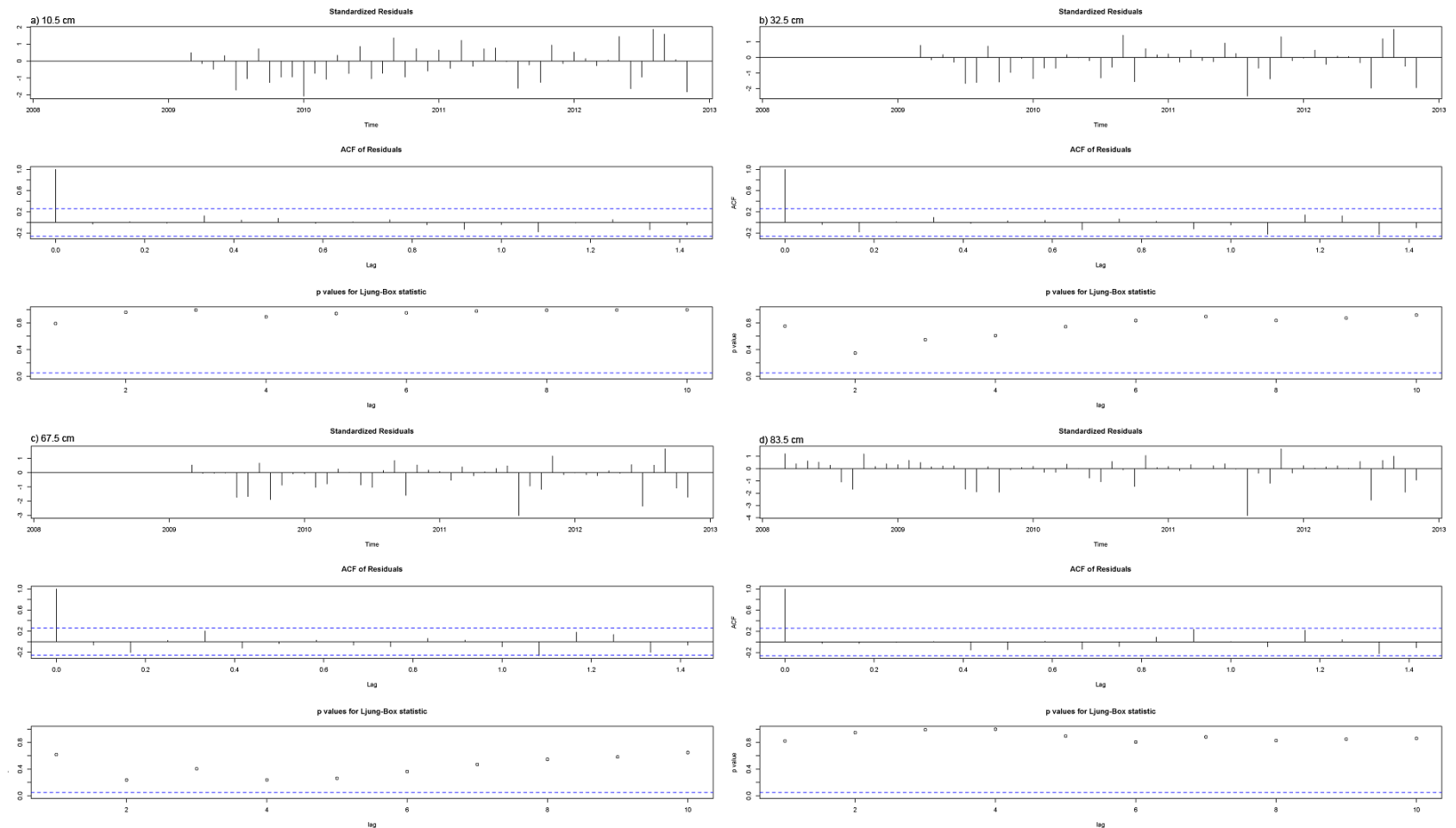

Figure 9. Standardized residuals, autocorrelation plot and Ljung-Box statistics for ARIMA models fitted to F1, F2, F3 and F4. 
Acknowledgements. This study was supported technically and logistically by the Brazilian Navy, MMA, UFV and FEAM-MG; grants were received from $\mathrm{CNPq}$. We also thank the Chilean Antarctic Institute (INACH) for technical and logistical support during field activities. This is a contribution of the Terrantar laboratory, part of the Brazilian National Institute of Cryospheric Science and Technology.

Edited by: A. Navas

\section{References}

Beyer, L., Bockheim, J. G., Campbell, I. B., and Claridge, G. G. C.: Genesis, properties and sensitivity of Antarctic Gelisols, Ant. Sci., 11, 387-398, 1999.

Bockheim, J. and Mcleod, M.: Soil distribution in the McMurdo Dry Valleys, Antarctica, Geoderma, 144, 43-49, 2008.

Bockheim, J. G.: Permafrost distribution in the Southern Circumpolar region and its Relation to the Environment: a Review and Recommendations for Further Research, Permafr. Perigl. Proc., 6, 27-45, 1995.

Burnham, K. P. and Anderson, D. R.: Model Selection and Multimodel Inference: A Practical Information-Theoretical Approach, 2nd Edn., New York, Springer-Verlag, 2002.

De Pablo, M. A., Blanco, J. J., Molina, A., Ramos, M., Quesada, A., and Vieira, G.: Interannual active layer variability at the Limnopolar Lake CALM site, Byers Peninsula, Livingston Island, Antarctica, Ant. Sci., 25, 197-180, 2013.

Ferron, F. A, Simões, J. C., Aquino, F. E., and Setzer, A. W.: Air temperature time series for King George Island, Antarctica, Pesquisa Antártica Brasileira, 4, 155-169, 2004.

Flanner, M. G., Shell, K. M., Barlage, M., Perovich, D. K., and Tschudi, M. A.: Radiative forcing and albedo feedback from the Northern Hemisphere cryosphere between 1979 and 2008, Nat. Geosci., 4, 151-155, 2011.

Guglielmin, M.: Ground surface temperature (GST), active layer, and permafrost monitoring in continental Antarctica, Permafr. Perigl. Proc., 17, 133-143, 2006.

Guglielmin, M., Evans, C. J. E., and Cannone, N.: Active layer thermal regime under different vegetation conditions in permafrost areas, A case study at Signy Island (Maritime Antarctica), Geoderma, 144, 73-85, 2008.

Hinkel, K. M.: Estimating seasonal values of thermal diffusivity in thawed and frozen soils using temperature time series, Cold Reg. Sci. Technol., 26, 1-15, 1997.

Hinkel, K. M., Outcalt, S. I., and Nelson, F. E.: Temperature variation and apparent thermal diffusivity in the refreezing active layer, Toolik Lake, Alaska, Permafr. Perigl. Proc., 14, 265-274, 1990.

Hinkel, K. M., Paetzold, F., Nelson, F. E., and Bockheim, J. G.: Patterns of soil temperature and moisture in the active layer and upper permafrost at Barrow, Alaska: 1993-1999, Glob. Planet. Change, 29, 293-309, 2001.

IPCC: Managing the Risks of Extreme Events and Disasters to Advance limate Change Adaptation, in: A Special Report of Working Groups I and II of the Intergovernmental Panel on Climate Change, edited by: Field, C. B., Barros, V., Stocker, T. F., Qin, D., Dokken, D. J., Ebi, K. L., Mastrandrea, M. D., Mach, K. J.,
Plattner, G.-K., Allen, S. K., Tignor, M., and Midgley, P. M., Cambridge University Press, Cambridge, UK, and New York, NY, USA, 582 pp., 2012.

Kane, D. L., Hinkel, K. M., Goering, D. J., Hinzman, L. D., and Outcalt, S. I.: Non-conductive heat transfer associated with frozen soils, Glob. Planet, Change, 29, 275-292, 2001

Köppen, W.: Das geographisca System der Klimate, in: Handbuch der Klimatologie, edited by: Köppen, W. and Geiger, G., Borntraeger, 1-44, 1936.

Ledley, T. S.: Sea ice: Multiyear cycles and white ice, J. Geophys. Res.-Atmospheres, 90, 2156-2202, 1985.

Mcgaw, R. W., Outcalt, S. I., and Ng, E.: Thermal properties and regime of wet tundra soils at Barrow, Alaska. Third International Conference on Permafrost, National Research Council of Canada, 1978, Ottawa, Canada, 47-53, 1978.

Michel, R. F. M., Schaefer, C. E. G. R., López-Martínez, J., Simas, F. N. B., Haus, N. W., Serrano, E., and Bockheim J. G.: Soils and landforms from Fildes Peninsula and Ardley Island, Maritime Antarctica, Geomorphology, 225, 76-86, 2014.

Mora, C., Frazier, A. G., Longman, R. J., Dacks, R. S., Walton, M. M., Tong, E. J., Sanchez, J. J., Kaiser, L. R., Stender, Y. O., Anderson, J. M., Ambrosino, C. M., Fernandez-Silva, I., Giuseffi, L. M., and Giambelluca, T. W.: The projected timing of climate departure from recent variability, Nature, 502, 183-187, 2013.

Moss, R. H., Edmonds, J. A., Hibbard, K. A., Manning, M. R., Rose, S. K., van Vuuren, D. P., Carter, T. R., Emori, S., Kainuma, M., Kram, T., Meehl, G. A., Mitchell, J. F., Nakicenovic, N., Riahi, K., Smith, S. J., Stouffer, R. J., Thomson, A. M., Weyant, J. P., and Wilbanks, T. J.: The next generation of scenarios for climate change research and assessment, Nature, 463, 747-56, 2010.

Nelson, F. E., Outcalt, S. I., Goodwin, C. W., and Hinkel, K. M.: Diurnal thermal regime in a peat-covered palsa, Toolik Lake, Alaska, Arctic, 38, 310-315, 1985.

Outcalt, S. I. and Hinkel, K. M.: Night frost modulation of nearsurface soil-water ion concentration and thermal fields, Phys. Geogr., 10, 336-346, 1989.

Øvstedal, D. O. and Lewis-Smith, R. I.: Lichens of Antarctica and South Georgia: guide to their identification and ecology, Cambridge, Cambridge University Press, 411 pp., 2001.

Rakusa-Suszczewski, S., Mietus, M., and Piasecki. J.: Weather and climate, in: The Maritime Antartic Coastal Ecosystem of Admiralty Bay, edited by: Rakusa-Sszczewski, Department of Antartic Biology, Polish Academy of Sciences, 19-25, 1993.

Simonov, M. I.: Physical-Geographic Descriptions of The Fildes Peninsula (South Shetland Islands), Polar Geogr., 1, 223-242, 1975.

Smellie, J. L., Pankhurst, R. J., Thomson, M. R. A., and Davies, R. E. S.: The Geology of the South Shetland Islands: VI. Stratigraphy, Geochemistry and Evolution, British Antarctic Survey Scientific Reports, 87, 1-85, 1984.

Smith, S. L. and Brown, J.: T7 Permafrost: Permafrost and seasonally frozen ground, Global Terrestrial Observing System, GTOS 62, Rome, 2009, 19 pp., 2009.

van den Broeke, M., Smeets, P., Ettema, J., van der Veen, C., van de Wal, R., and Oerlemans, J.: Partitioning of melt energy and meltwater fluxes in the ablation zone of the west Greenland ice sheet, The Cryosphere, 2, 179-189, doi:10.5194/tc-2179-2008, 2008. 
Vieira, G., Bockheim, J., Guglielmin, M., Balks, M., Andrey, A., Boelhouwers, J., Cannone, N., Ganzer, L., Gilchinsky, D., Goryachkin, S., López-Martínez, J., Meiklejohn, I., Raffi, R., Ramos, M., Schaefer, C., Serrano, E., Simas, F., Sletten, R., and Wagner, D.: Thermal state of Antarctic permafrost and active-layer dynamics: Advances during the International Polar Year 20072008, Permafr. Perigl. Proc., 21, 182-197, 2010.
Wen, J., Xie, Z., Han, J., and Lluberas, A.: Climate, mass balance and glacial changes on small dome of Collins Ice Cap, King George Island, Antarctica, Antarct. Res., 5, 52-61, 1994. 